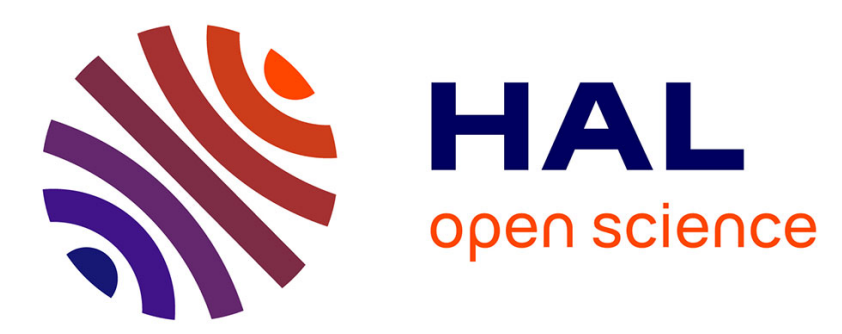

\title{
The heterogeneity of humus components in a virgin beech forest
}

Nikola Patzel, Jean-François Ponge

\section{To cite this version:}

Nikola Patzel, Jean-François Ponge. The heterogeneity of humus components in a virgin beech forest. European Journal of Soil Biology, 2001, 37 (2), pp.117-124. 10.1016/S1164-5563(01)01076-7 . hal00501728

\section{HAL Id: hal-00501728 \\ https://hal.science/hal-00501728}

Submitted on 12 Jul 2010

HAL is a multi-disciplinary open access archive for the deposit and dissemination of scientific research documents, whether they are published or not. The documents may come from teaching and research institutions in France or abroad, or from public or private research centers.
L'archive ouverte pluridisciplinaire HAL, est destinée au dépôt et à la diffusion de documents scientifiques de niveau recherche, publiés ou non, émanant des établissements d'enseignement et de recherche français ou étrangers, des laboratoires publics ou privés. 


\section{The heterogeneity of humus components in a virgin beech forest}

Nikola Patzel, Jean-François Ponge*

Laboratoire d'Écologie Générale, Museum National d'Histoire Naturelle, 4 avenue du PetitChateau, 91800 Brunoy, France

*fax +33 1 60479213, e-mail: jean-francois.ponge@wanadoo.fr

Running title: Heterogeneity of humus components

Abstract: A non-random sampling design allowed to distinguish within a virgin beech ecosystem two main components of humus profile heterogeneity. The stratification of the profile into horizons reflects changes in the composition of the soil/litter matrix occurring under the influence of the anisotropic deposition of leaf and wood litter and the stratified occurrence of soil organisms (roots, microbes, animals). The horizontal heterogeneity is mainly influenced by changes in vegetation, in particular the decreasing influence of beech (and the increasing influence of ground vegetation) when passing from the tree trunk base, where the influence of the tree reaches a maximum, to the centre of adjacent gaps where the influence of beech is replaced by that of another vegetation. The use of multivariate methods, used for description rather than for modelling, is suggested to be the best procedure for understanding patterns underlying heterogeneity without a priori assumptions.

Keywords: Beech, Heterogeneity, Litter, Humus, Fauna, Correspondence analysis

Résumé: L'hétérogénéité des composants de l'humus dans une forêt vierge de hêtre. Un échantillonnage dirigé a permis de distinguer dans une hêtraie naturelle deux composants principaux de l'hétérogénéité des profils d'humus. La stratification des profils en horizons reflète les changements intervenant dans la composition de la matrice sous l'influence de l'anisotropie des dépôts de litière et la stratification verticale des organismes du sol (racines, microorganismes, animaux). L'hétérogénéité horizontale est influencée principalement par les 
changements de végétation, en particulier l'influence décroissante du hêtre (et l'influence croissante de la végétation au sol) depuis la base du tronc, où l'influence de l'arbre atteint un maximum, jusqu'au centre des trouées adjacentes où l'influence de l'arbre est remplacée par celle d'une autre végétation. L'utilisation de méthodes multivariées, dans le but de décrire les données plutôt que de les modéliser, est considérée comme le moyen le plus adéquat pour appréhender sans a priori les schémas sous-jacents à l'hétérogénéité.

Mots-clés: Hêtre, Hétérogénéité, Litière, Humus, Faune, Analyse des correspondances 


\section{INTRODUCTION}

The existence of small-scale horizontal and vertical variation of soil properties is well known [29, $32,38]$, but most of the recent investigations on small-scale heterogeneity are focussed on mathematical modelling $[12,17,39]$. Therefore there is still a need for studies which minimise modelling assumptions and abstractions in order to be as close as possible to observable soil properties.

Small-scale variations in the composition of topsoil profiles may occur under the influence of vegetation changes $[4,25,26]$ or microtopography $[16,22]$. Both may reflect changes in site conditions occurring in the course of time $[7,10]$. In virgin forests, an important component of horizontal heterogeneity, the eco-unit, can be interpreted as a stage in a successional process starting from the so-called zero-event [28]. Other well-known patterns in woodlands are the acidification of the soil which occurs near trunk bases $[5,45]$.

The site "La Tillaie", in the Fontainebleau state forest near Paris (France), is a beech (Fagus sylvatica L.) ecosystem unmanaged for at least 400 years [20, 24]. Therefore it has been thought to use it for the study of natural small-scale heterogeneity and short-term soil changes as well. Several studies were conducted on the factors explaining meso-scale variations in regeneration patterns, humus profiles and earthworm communities [36, 37, 42]. Small-scale changes in regeneration patterns and earthworm communities were studied using repetitive sampling along transect lines or cross-line grids $[11,30]$. Until today no investigation on patterns of humus changes at a very small scale has been done for this type of forest.

In this study the focus was on what can be seen at the micromorphological scale, using identification of humus components and their quantitative analysis as tools to characterize samples [7, 29, 32]. We raised the following question: can horizontal as well as vertical distribution patterns of humus components be explained by simple ecological processes? This 
is part of a long-term investigation on forest ecosystems aiming at resolving their apparent complexity by selecting scales appropriate to the process to be understood [33].

\section{MATERIAL AND METHODS}

\subsection{Study site}

The biological reserve of "La Tillaie" (33ha) is mainly composed of beech growing on a sandy soil (Fontainebleau sand) overlying a limestone table [37]. The study site is a 0.5 ha area the vegetation and topsoil features of which have been already described by Peltier et al. [30]. It encompasses partly Plot 1 (Melico-Fagetum) in Koop and Hilgen [20]. Plots K, K' and P in Ponge et al. [37] and Topoliantz and Ponge [42] were located in the study site, too. During winter 1990 a severe storm felled seven tall trees, creating multiple gaps [30] which were not present at the time of the study by Koop and Hilgen [20]. Ground vegetation is mainly made of butcher's broom (Ruscus aculeatus L.), growing as dense carpets in the shade of beech, wood melick (Melica uniflora Retz.) and pokeweed (Phytolacca americana L.) forming single-species patches in sunny places. The microtopography created by ancient windthrows [10] was at the origin of mounds and pits with wind-blown or collected litter, respectively. Soils are sandy, strongly acidic. Soil physico-chemical properties of plots $\mathrm{K}$ and $\mathrm{K}^{\prime}$ (based on random sampling within plots) are presented in Table I. Despite soil acidity, humus forms are of the mull type, due to earthworm activity in places where trees and deep-burrowing earthworms have access to the underlying limestone table [37]. Depth of the limestone table (measured at the centre of the plot) was 129,67 and $96 \mathrm{~cm}$ on plots $\mathrm{K}, \mathrm{K}^{\prime}$ and $\mathrm{P}$, respectively [37].

\subsection{Sampling procedure}

Thirteen humus profiles were selected on the basis of visible heterogeneity of vegetation and microtopography (Table II). Sampling of humus profiles was done within a week in July 1992. Each sample was unique, being representative of a combination of environmental conditions which prevailed in the study site at the time of sampling: beech adult or young, sun or shade, 
ground bare or covered by vegetation (Ruscus, Melica, Phytolacca), mound or pit, near the trunk or far from the trunk. Samples were taken according to the method of Bernier and Ponge [7]. A soil block $5 \times 5 \times 15 \mathrm{~cm}$ was dressed with a sharp knife. Different layers were thoroughly separated from the top to the bottom of the profile on the basis of morphological differences which could be perceived to the naked eye. No attempt was made to follow nomenclature of horizons following Babel [2], Green et al. [18] or Brêthes et al. [9]. Nevertheless each layer was indicated as OL (fresh litter), OF (fragmented litter), $\mathrm{OH}$ (pelletized and humified litter) and $\mathrm{A}$ (hemorganic), followed by a number according to its sampling rank (OL1, OL2,...). All layers (129 in total) were immediately fixed into $95 \%$ ethyl alcohol then transported to the laboratory to be studied later.

Each layer was transferred to a Petri dish filled with alcohol, then thoroughly spread over the whole surface of the dish with as little disturbance as possible. A transparent plastic sheet with a 200 points grid was then placed above the sample for identifying and counting humus components under a dissecting microscope. Countings were summed up for each category then transformed into percentages of solid matter. Due to the sandy nature of the soil, some poorly structured hemorganic or mineral assemblages were dispersed, forming a muddy deposit at the bottom of plastic tubes which were used for the fixation and transport of humus layers, contrary to other studies using the same method $[7,13,29]$. Such fine material without any indication of coherent structure was thus discarded in the analysis. Sixty categories were identified in the whole set of humus layers (Table III).

\subsection{Data analysis}

Data (percentages of occurrence of a given category in a given layer) were analysed by correspondence analysis [6, 19], using 129 samples (layers $\mathrm{x}$ profiles) as observations and 60 humus components as active variables. Passive variables ( $\mathrm{OL}$ horizon, $\mathrm{OF}$ horizon, $\mathrm{OH}$ horizon, A horizon, Beech, Melica, Ruscus, Gap, Trunk base, Litter accumulation, Trampling) were added, indicating profile or horizon features, and coded as 1 or 0 . All variables (active and passive) were transformed according to the method of Ponge and Delhaye [36]. For each 
variable the data were refocused and reweighted according to the formula: $x=(x-m) / s+20, m$ being the mean and $s$ the standard error of the variable.

\section{RESULTS}

The projection of active and passive variables in the plane of the first two axes (12\% and $8 \%$ of the total variance, respectively) expressed the vertical heterogeneity, each horizon being characterized by a particular composition (Fig. 1). The OL horizon was mainly made of entire leaves of beech (categories 1, 3, 8). The OF horizon had a more diverse composition, being made of skeletonized beech leaves (categories 5 and 6), fragmented bud scales of beech (category 13), beechnuts (categories 15 and 16) and organic faecal material (categories 45, 52). Some categories were common to OL and OF horizon, such as beech leaves browsed by fauna (categories 2 and 4), entire bud scales of beech (categories 11 and 12), miscellaneous organs of beech (categories 8, 9, 10) and beech wood (category 19). Thus OL and OF horizons were distinguished more by faunal activity (skeletonization of leaves) than by microbial activity (bleaching of leaves). The $\mathrm{OH}$ horizon was characterized by humified organic matter (categories $41,54,55$ ), enchytraeid faeces (category 47 ) and the fine root system of beech, mycorrhizae comprised (categories 25, 26, 29, 30, 32), as well as by individual sand grains (category 57). The A horizon was mostly characterized by compacted hemorganic material (category 56) and, to a lower extent, by larger roots of beech (categories 27 and 28), Cenococcum mycorrhizae and sclerotia (categories 31 and 33), and recalcitrant material such as snail shells (category 58) and arthropod cuticles (category 59). Holorganic faeces of oribatid mites, millipedes, woodlice and slugs (categories $48,49,50,51$, respectively) were not placed far from the origin, but rather between the OL/OF group and the A horizon, showing that these categories were mostly present in humus profiles where the $\mathrm{OH}$ horizon was absent (mull), while enchytraeid faeces were characteristic of the $\mathrm{OH}$ horizon of moder. Passive variables indicating site conditions were placed not far from the origin, except "Melica" and "Gap" which were projected on the negative side of Axis 2. This indicated that the pattern depicted by the plane of the first two axes

mostly concerned vertical heterogeneity (horizons) rather than horizontal heterogeneity (vegetation, trampling, pits with litter accumulation, vicinity of trunk bases), except that carpets 
of Melica within gaps where characterized by the direct passage from an OL horizon to an $\mathrm{A}$ horizon, thus by a rapid incorporation of litter to the mineral soil.

The projection of passive variables in the plane of Axes 1 and $3(12 \%$ and $7 \%$ of the total variance, respectively) showed features related to horizontal heterogeneity (Fig. 2). This was indicated by the position of passive variables along Axis 3. "Beech" and "Gap" were opposed along this axis. On the positive side of Axis 3, "Trunk base" was still farther from the origin than "Beech". On the negative side of Axis 3 "Phytolacca" and "Melica" were associated with "Gap". "Ruscus", "Litter accumulation" and "Trampling" were placed in an intermediary position, not far from the origin. Thus Axis 3 can be interpreted as showing the increasing influence of beech, starting from places where beech was replaced by another vegetation (mainly wood melick and pokeweed) up to the close vicinity of the beech trunk. The projection along Axis 3 of passive variables indicating whole humus profiles reinforces this interpretation. Profiles 1 and 2 (at 50 $\mathrm{cm}$ and $100 \mathrm{~cm}$ from the tree trunk, respectively) are projected on Axis 3 in accordance with their distance to the trunk base. If we consider Profile 4 as typical of the closed canopy of beech (with the shade-tolerant butcher's broom underneath), the series 1, 2, 4 indicates a decreasing influence of beech according to the distance to the tree trunk. Conversely, in gaps, profiles under shade-intolerant vegetation $(6,7,10,11)$ are farther from the origin than profiles with only a litter cover of beech $(8,9)$. Places under beech, far from the trunk and without any other vegetation $(3,5,13)$ are placed in an intermediary position.

The projection of active variables in the plane of Axes 1 and 3 (Fig. 3) showed that the composition of $\mathrm{OH}$ and $\mathrm{A}$ horizons varied according to the degree of influence of beech (expressed by Axis 3). The vicinity of the trunk of beech was characterized by the living root system of beech (categories 25, 27, 29, 31), holorganic faecal material (category 42), sand grains (category 57) and recalcitrant material (categories 58, 59). Conversely, gap vegetation was characterized by subterranean and aerial parts of wood melick and pokeweed (categories $22,23,36,37,38,39,40$ ), dead roots of beech (categories $26,28,30$ ), organic-dominant and hemorganic masses (categories 55,56) and enchytraeid faeces (category 47). OL and OF horizons were seemingly unaffected by the segregation depicted by Axis 3, except for aerial 
parts of wood melick (categories 22, 23). The position along Axis 3 of the passive variables representing horizon names showed that the A horizon was more typical of gaps and the $\mathrm{OH}$ horizon was rather associated with the beech effect. Nevertheless enchytraeid faeces (category 47), a component of the $\mathrm{OH}$ horizon (Fig. 1), were rather associated with gaps, being projected on the negative side of this axis.

\section{DISCUSSION}

The use of correspondence analysis allowed to discern global trends in vertical as well as horizontal heterogeneity. The same method was used to analyse the composition of topsoil horizons in managed beech forests of the Belgian Ardennes [32]. Although the parent rock differed in hardness (sandstone in the Ardennes, fine sand in La Tillaie) both forests had strongly acidic soils. The composition of the four horizons (OL, OF, OH and A) did not differ to a great extent between both studies, but the composition of $\mathrm{OH}$ and $\mathrm{A}$ horizons differed more in the present study, indicating a sharper transition between these horizons. This was probably due to the fact that moder, including dysmoder with a thick $\mathrm{OH}$ horizon and complete absence of earthworms, was the dominant humus form in the Belgian sites, while the contrary was observed in the present study zone where earthworms were present everywhere $[36,37]$. To the light of these two studies it should be underlined that the fine root system of beech, with its mycorrhizae, was better expressed in the $\mathrm{OH}$ horizon than in the OF horizon. This differs markedly from what had been observed in a Scots fine stand by Ponge [31], where the OF horizon exhibited a profuse development of mycorrhizal roots and associated mycelia permeating the fragmented litter, the $\mathrm{OH}$ horizon being mainly made of dead material. To the light of observation [27] and experimental proof [3] it could be suggested that the development of a dense mycorrhizal root system in the OF horizon (thus making the $\mathrm{OH}$ horizon a "dead" horizon) is indicative of an evolution towards mor through the development of an OM horizon, i.e. an organic horizon made of poorly humified litter with a poor content in animal faeces [35].

The poor stability of mineral and hemorganic assemblages in sandy soils [8] was responsible for the compaction of earthworm-mediated plant and soil material, making the A horizon mostly 
made of compact hemorganic masses without any crumby structure. Faecal material was recognizable only when still in a fresh state, thus it was identified as such in the $\mathrm{OH}$ horizon only. An exception was enchytraeid faecal material, which was observed within the A horizon (Fig. 3). Enchytraeids are known to ingest hemorganic as well as holorganic material and to tunnel easily through earthworm casts [14, 43].

The influence of vegetation was expressed by Axis 3 of correspondence analysis, opposing beech (and more especially the trunk base) to herbaceous vegetation living in the gaps at the time of the study (Melica, Phytolacca). Similar methods allowed to discern small-scale patterns, starting from the tree trunk base to the centre of adjacent gaps filled with another vegetation [29]. Beside evident differences in the state of the beech root system (living under beech, dead in the gaps), the presence and absence of some components of the humus profile could be used as clues for identifying changes in the biological functioning of the soil which occur after a windthrow. In a previous study on La Tillaie conducted during the same year, Ponge and Delhaye [36] demonstrated that earthworm populations (mainly soil-dwelling species) collapsed in gaps recently opened by storms. In the present study, enchytraeid faeces were mainly present in A horizons of the gaps. The balance between enchytraeid and earthworm activity could have been affected by sudden changes in food resources and microclimate following the local death of beech such as a lesser litter input combined with a more intense mineralization of organic matter in the A horizon, and the dryness of the soil surface $[15,41]$. It has been observed that impoverishment of the soil was detrimental to earthworms but favoured enchytraeids which are more resistant to soil dryness and poor nutrient status [14]. This could explain why earthworm faecal material (categories 45,46 ) was rather associated to the beech trees (positive side of Axis 3), contrary to enchytraeid faecal material (category 47) which were associated to the gaps (negative side of Axis 3).

The acidifying influence of the stemflow area has been recorded times and again under beech $[44,21,23]$ and was here visible in the respective position of Profiles $1(50 \mathrm{~cm}$ from the trunk base) and 2 (100 cm from the trunk base) on the positive side of Axis 3 (Fig. 2). This was due to changes in the composition of humus profiles, with more holorganic faecal material 
accumulated near the trunk base, as this has been already observed under oak by Deschaseaux and Ponge [13]. The positive influence of full-grown beech (compared to the pole stage, i.e. young individuals still growing in height) on soil-dwelling earthworms, demonstrated by Ponge and Delhaye [36] on the La Tillaie site, thus needs to be reconsidered, taking into account small-scale changes occurring beneath an individual tree. The improvement of soil biological activity which occurs during maturity then senescence of forest ecosystems $[1,7,36]$ does not hold for the small area (less than $1 \mathrm{~m}$ diameter) surrounding the trunk.

The sampling design did not use replication as a basis for statistical analysis. Rather, each sample (layer $x$ profile) represented an unique case, having its own story to tell us. Nevertheless the use of a multivariate method for data analysis allowed to incorporate these separate samples into a composite sample, the structure of it was analysed without any a priori hypotheses. We consider that this composite sample was representative of the heterogeneity which was perceptible to the naked eye in the study site. This was preferred to a randomised design based on a priori hypotheses (orthogonal comparisons between groups), given that when studying heterogeneity, what we call ground noise (or residual variance) in classical statistical inference [40] is actually the matter of our study.

The use of correspondence analysis for the data treatment did not allow to test separately the significance of categories for the separation of horizons and/or profiles. It gave only an overall picture of the structure of the data but might help to ask questions such as i) are there discrepancies (expected or not) between horizons or profiles concerning the composition of the solid matter, ii) what are the categories most closely involved in these discrepancies, but without deciding whether found relationships were significant or not. The advantage is that no null hypothesis has to be built as a prerequisite to data treatment, the absence of structure in the data being considered as trivial and thus needing not to be tested [6]. The disadvantage is that rules of statistical inference are violated. In natural forests, where the highest variety of vegetation and micro-climate conditions is exhibited [28], statistical inference can hardly help to understand what is hidden under the apparent complexity of the virgin forest. 


\section{REFERENCES}

[1] Arpin P., Ponge J.F., Faille A., Blandin P., Diversity and dynamics of eco-units in the biological reserves of the Fontainebleau forest (France): contribution of soil biology to a functional approach, Eur. J. Soil Biol. 34 (1998) 167-177.

[2] Babel U., Gliederung und Beschreibung des Humusprofils in mitteleuropäischen Wäldern, Geoderma 5 (1971) 297-324.

[3] Babel U., Influence of high densities of fine roots of Norway spruce on processes in humus covers, Ecol. Bull. 25 (1977) 584-586.

[4] Babel U., Ehrmann O., Krebs M., Relationships between earthworms and some plant species in a meadow, Soil Biol. Biochem. 24 (1992) 1477-1481.

[5] Beniamino F., Ponge J.F., Arpin P., Soil acidification under the crown of oak trees. I. Spatial distribution, For. Ecol. Manag. 40 (1991) 221-232.

[6] Benzécri J.P., L'analyse des données. II. L'analyse des correspondances, Dunod, Paris, 1973.

[7] Bernier N., Ponge J.F., Humus form dynamics during the sylvogenetic cycle in a mountain spruce forest, Soil Biol. Biochem. 26 (1994) 183-220.

[8] Brady N.C., Weil R.R., The nature and properties of soils, $12^{\text {th }}$ ed., Prentice Hall, Upper Saddle River, 1999.

[9] Brêthes A., Brun J.J., Jabiol B., Ponge J.F., Toutain F., Classification of forest humus forms: a French proposal, Ann. Sci. For. 52 (1995) 535-546. 
[10] Brown J.L., Étude de la perturbation des horizons du sol par un arbre qui se renverse et de son impact sur la pédogénèse, Can. J. Soil Sci. 57 (1977) 173-186.

[11] Campana C., Gauvin S., Ponge J.F., Influence of ground cover on earthworm species assemblages in an unmanaged beech forest: linear gradient studies (submitted).

[12] Cannavacciulo M., Bellido A., Cluzeau A., Gascuel C., Trehen A., A geostatistical approach to the study of earthworm distribution in grassland, Appl. Soil Ecol. 9 (1998) 345-349.

[13] Deschaseaux A., Ponge J.F., Changes in the composition of humus profiles near the trunk base of an oak tree [Quercus petraea (Mattus.) Liebl.], Eur. J. Soil Biol. 37 (2001) in press.

[14] Didden W.A.M., Ecology of terrestrial Enchytraeidae, Pedobiologia 37 (1993) 2-29.

[15] Fardjah M., Lemée G., Pontailler J.Y., Dynamique comparée de l'eau sous hêtraie et dans des coupes nues ou à Calamagrostis epigeios en forêt de Fontainebleau, Bull. Ecol. 11 (1980) 11-31.

[16] Garay I., Hafidi N., Study of a mixed forest litter of hornbeam (Carpinus betulus L.) and oak (Quercus sessiliflora Smith). III. Organization of the edaphic marcoarthropod community as a function of litter quantity, Acta Oecol. 11 (1990) 43-60.

[17] Gourbière F., Debouzie D., Spatial distribution and estimation of forest floor components in a 37-year-old Casuarina equisetifolia (Forst.) plantation in Coastal Senegal. Soil Biol. Biochem. 27 (1995) 297-304.

[18] Green R.N., Trowbridge R.L., Klinka K., Towards a taxonomic classification of humus forms, For. Sci. Monogr. 29 (1993) 1-49. 
[19] Greenacre M.J., Theory and applications of correspondence analysis, Academic Press, London, 1984.

[20] Koop H., Hilgen P., Forest dynamics and regeneration mosaic shifts in unexploited beech (Fagus sylvatica) stands at Fontainebleau (France), For. Ecol. Manag. 20 (1987) 135-150.

[21] Kopeszki H., An active bioindication method for the diagnosis of soil properties using Collembola, pedobiologia 41 (1997) 159-166.

[22] Kopeszki H., Jandl R., Die Mesofauna, insbesondere Collembolenfauna, im BuchenWienerwald in Abhängigkeit von Streu-Akkumulation und -Depletion. Zool. Anz. 233 (1994) 123-134.

[23] Kumpfer W., Heyser W., Effects of stemflow on the mycorrhiza of beech (Fagus sylvaticus L.), in: Gianinazzi-Pearson V., Gianinazzi S. (Eds.), Physiological and genetical aspects of mycorrhizae, INRA, Paris, 1986, pp. 745-750.

[24] Lemée G., Les réserves biologiques de la Tillai et du Gros-Fouteau en forêt de Fontainebleau, écocomplexes climaciques, Lett. Bot. 137 (1990) 47-62.

[25] Leroy C., Toutain F., Lavelle P., Variations des caractéristiques de l'humus forestier d'un sol ferrallitique (Guyane) selon l'essence arborée consodérée. Résultats préliminaires, Cah. ORSTOM Pédol. 27 (1992) 37-48.

[26] Loranger G., Ponge J.F., Lavelle P., Development of humus forms in two secondary semi-evergreen tropical forests (submitted). 
[27] Meyer F.H., Göttsche D., Distribution of root tips and tender roots of beech, in: Ellenberg H. (Ed.), Ecological studies. Analysis and synthesis, vol. 2, Springer-Verlag, Berlin, 1971, pp. 47-52.

[28] Oldeman, R.A.A., Forests: elements of silvology, Springer-Verlag, Berlin, 1990.

[29] Peltier A., Ponge J.F., Jordana R., Ariño A., Humus forms in Mediterranean scrublands with aleppo pine, Soil Sci. Soc. Am. J. 65 (2001), in press.

[30] Peltier A., Touzet M.C., Armengaud C., Ponge J.F., Establishment of Fagus sylvatica and Fraxinus excelsior in an old-growth beech forest, J. Veg. Sci. 8 (1997) 13-20.

[31] Ponge J.F., Étude écologique d'un humus forestier par l'observation d'un petit volume. III. La couche $F_{1}$ d'un moder sous Pinus sylvestris, Pedobiologia 31 (1988) 1-64.

[32] Ponge J.F., Horizons and humus forms in beech forests of the Belgian Ardennes, Soil Sci. Soc. Am. J. 63 (1999) 1888-1901.

[33] Ponge J.F., Heterogeneity in soil animal communities and the development of humus forms, in: Rastin N., Bauhus J. (Eds.), Going underground. Ecological studies in forests soils, Research Signpost, Trivandrum, 1999, pp. 33-44.

[34] Ponge J.F., Arpin P., Sondag F., Delecour F., Soil fauna and site assessment in beech stands of the Belgian Ardennes, Can. J. For. Res. 27 (1997) 2053-2064.

[35] Ponge J.F., Charnet F., Allouard J.M., Comment distinguer dysmoder et mor? L'exemple de la forêt domaniale de Perche-Trappe (Orne), Rev. For. Fr. 52 (2000) 2337. 
[36] Ponge J.F., Delhaye (L.), The heterogeneity of humus profiles and earthworm communities in a virgin beech forest, Biology and Fertility of Soils 20 (1995), 24-32.

[37] Ponge J.F., Patzel N., Delhaye L., Devigne E., Levieux C., Beros P., Wittebroodt R., Interactions between earthworms, litter and trees in an old-growth beech forest, Biol. Fertil. Soils 29 (1999) 360-370.

[38] Riha S.J., James B.R., Senesac G.P., Pallant E., Spatial variability of soil pH and organic matter in forest plantations, Soil Sci. Soc. Am. J. 50 (1986) 1347-1352.

[39] Rossi J.P., Lavelle P., Albrecht A., Relationships between spatial pattern of the endogeic earthworm Polypheretima elongata and soil heterogeneity, Soil Biol. Biochem. 29 (1997) 485-488.

[40] Sokal R.R., Rohlf F.J., Biometry. The principles and practice of statistics in biological research, $3^{\text {rd }}$ ed., Freeman, New York, 1995.

[41] Terlinden M., André P., Effets de l'intensité d'éclaircie sur les horizons organiques et hémiorganiques du sol en futaie équienne de Picea abies, Pedobiologia 32 (1988) 301 309.

[42] Topoliantz S., Ponge J.F., Influence of site conditions on the survival of Fagus sylvatica seedlings in an old-growth beech forest, J. Veg. Sci. 11 (2000) 369-374.

[43] Topoliantz S., Ponge J.F., Viaux P., Earthworm and enchytraeid activity under different arable faming systems, as exemplified by biogenic structures, Plant Soil (in press).

[44] Wittig, R., Neite H., Acid indicators around the trunk base of Fagus sylvatica in limestone and loess beechwoods: distribution pattern and phytosociological problems, Vegetatio 64 (1985) 113-119. 
[45] Zinke P.J., The pattern of influence of individual forest trees on soil properties, Ecology 43 (1962) 130-133. 


\section{LEGENDS OF FIGURES}

Fig. 1. Correspondence analysis. Projection of active variables (categories of humus components) and passive variables (horizon names, ecological indicators) in the plane of the first two axes. Categories were coded as in Table III.

Fig. 2. Correspondence analysis. Projection of passive variables (horizon names and profile numbers) in the plane of Axes 1 and 3.

Fig. 3. Correspondence analysis. Projection of active variables (categories of humus components) and passive variables (horizon names, ecological indicators) in the plane of Axes 1 and 3. Categories were coded as in Table III. 
Table I. Physicochemical features of $A$ horizons in plots $\mathrm{K}$ and $\mathrm{K}$ '. Methods according to Ponge et al. [35].

Data are means of six replicates \pm SE.

\begin{tabular}{lll}
\hline & Plot K & Plot K' \\
\hline Water pH & $3.64 \pm 0.07$ & $3.76 \pm 0.07$ \\
$\mathrm{KCl} \mathrm{pH}$ & $3.30 \pm 0.09$ & $3.43 \pm 0.09$ \\
$\mathrm{C} / \mathrm{N}$ & $17.1 \pm 1.4$ & $16.6 \pm 1.3$ \\
Total P \%o & $0.21 \pm 0.01$ & $0.22 \pm 0.01$ \\
Total Fe \%o & $6.53 \pm 0.33$ & $7.28 \pm 0.30$ \\
Total Ca \%o & $0.38 \pm 0.07$ & $0.62 \pm 0.12$ \\
Total Mg \%o & $0.42 \pm 0.02$ & $0.48 \pm 0.02$ \\
Total K \%o & $0.25 \pm 0.02$ & $0.37 \pm 0.03$ \\
Exchangeable Ca mg.kg & $98 \pm 16$ & $119 \pm 24$ \\
Exchangeable $\mathrm{Mg} \mathrm{mg}^{-1} \mathrm{~kg}^{-1}$ & $12.6 \pm 1.6$ & $13.6 \pm 1.9$ \\
Exchangeable K mg.kg & $31.9 \pm 6.5$ & $24.8 \pm 1.9$ \\
Clay \% & $6.23 \pm 0.60$ & $6.81 \pm 0.50$ \\
Silt \% & $19.26 \pm 0.72$ & $20.53 \pm 0.62$ \\
Sand \% & $71.03 \pm 0.49$ & $70.96 \pm 0.39$ \\
\hline
\end{tabular}


Table II. Humus profiles sampled in the study site. Plot codes refer to Ponge et al. [35].

\section{Profile Plot Description}

\begin{tabular}{lll}
\hline 1 & $\mathrm{~K}$ & Under full-grown beech, $50 \mathrm{~cm}$ from the trunk base, no ground vegetation \\
2 & $\mathrm{~K}$ & Under full-grown beech, $100 \mathrm{~cm}$ from the trunk base, no ground vegetation \\
3 & $\mathrm{~K}$ & Under full-grown beech, far from the trunk, old mound without leaf litter, no ground vegetation, signs of past trampling \\
4 & $\mathrm{~K}$ & Under full-grown beech, far from the trunk, litter accumulated under Ruscus, signs of past trampling \\
5 & $\mathrm{~K}$ & Under full-grown beech, far from the trunk, litter accumulated under overlapping crowns \\
6 & $\mathrm{~K}^{\prime}$ & In a multiple gap, under Phytolacca, near a fallen log of beech \\
7 & $\mathrm{~K}^{\prime}$ & In a multiple gap, under Melica \\
8 & $\mathrm{~K}^{\prime}$ & In a multiple gap, no ground vegetation \\
9 & & In a single gap, no ground vegetation \\
10 & & In a single gap, under Phytolacca \\
11 & & In a single gap, under Melica \\
12 & $\mathrm{P}$ & Under full-grown beech, Ruscus \\
13 & $\mathrm{P}$ & Under full-grown beech, no ground vegetation \\
\hline
\end{tabular}


Table III. List of humus components (categories) found in the whole set of 129 samples

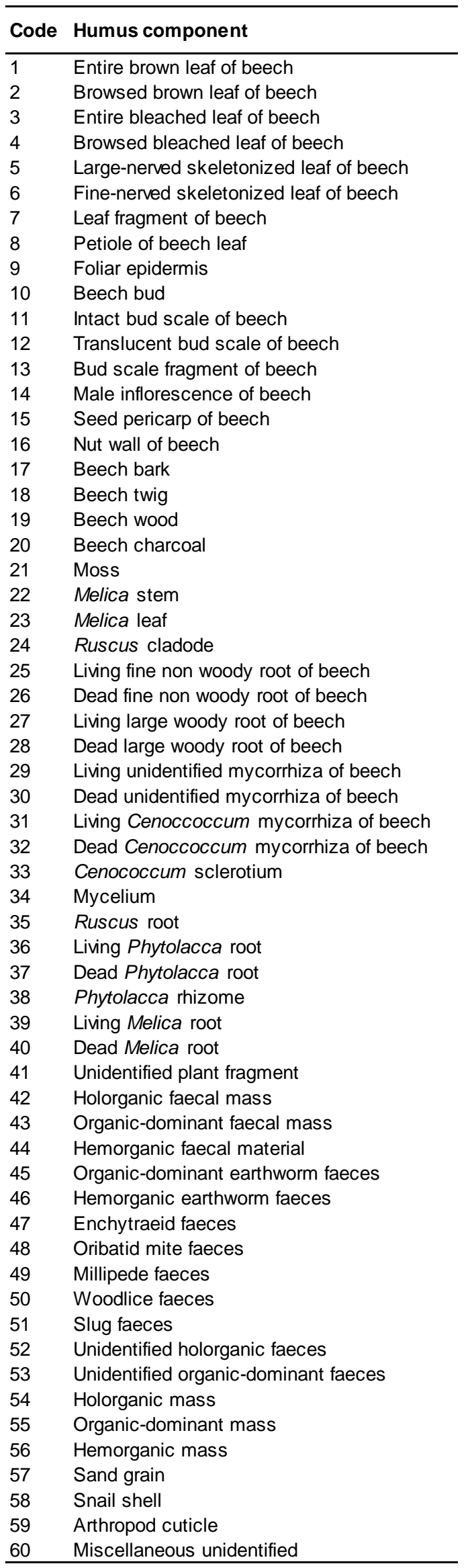




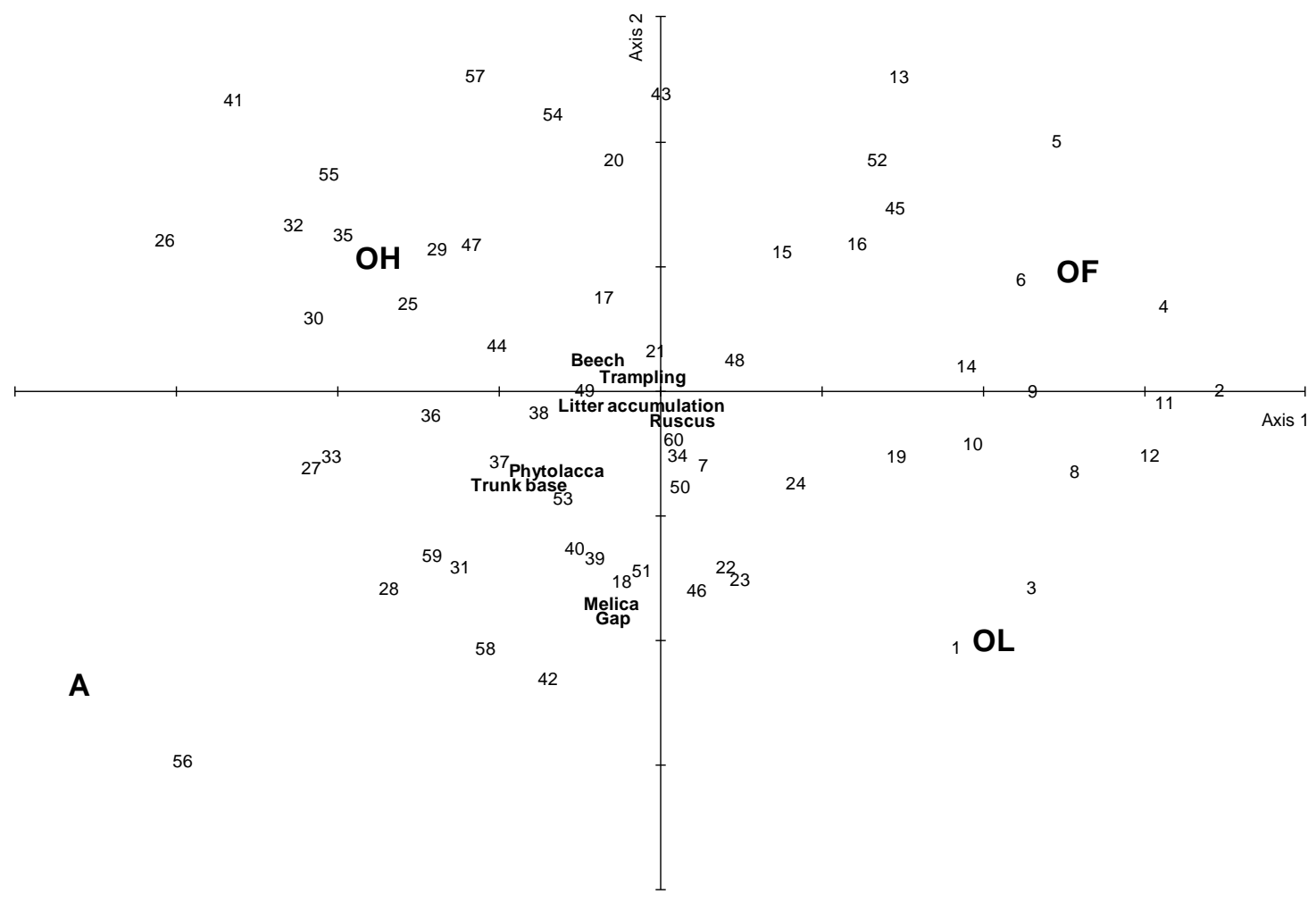

Fig. 1 


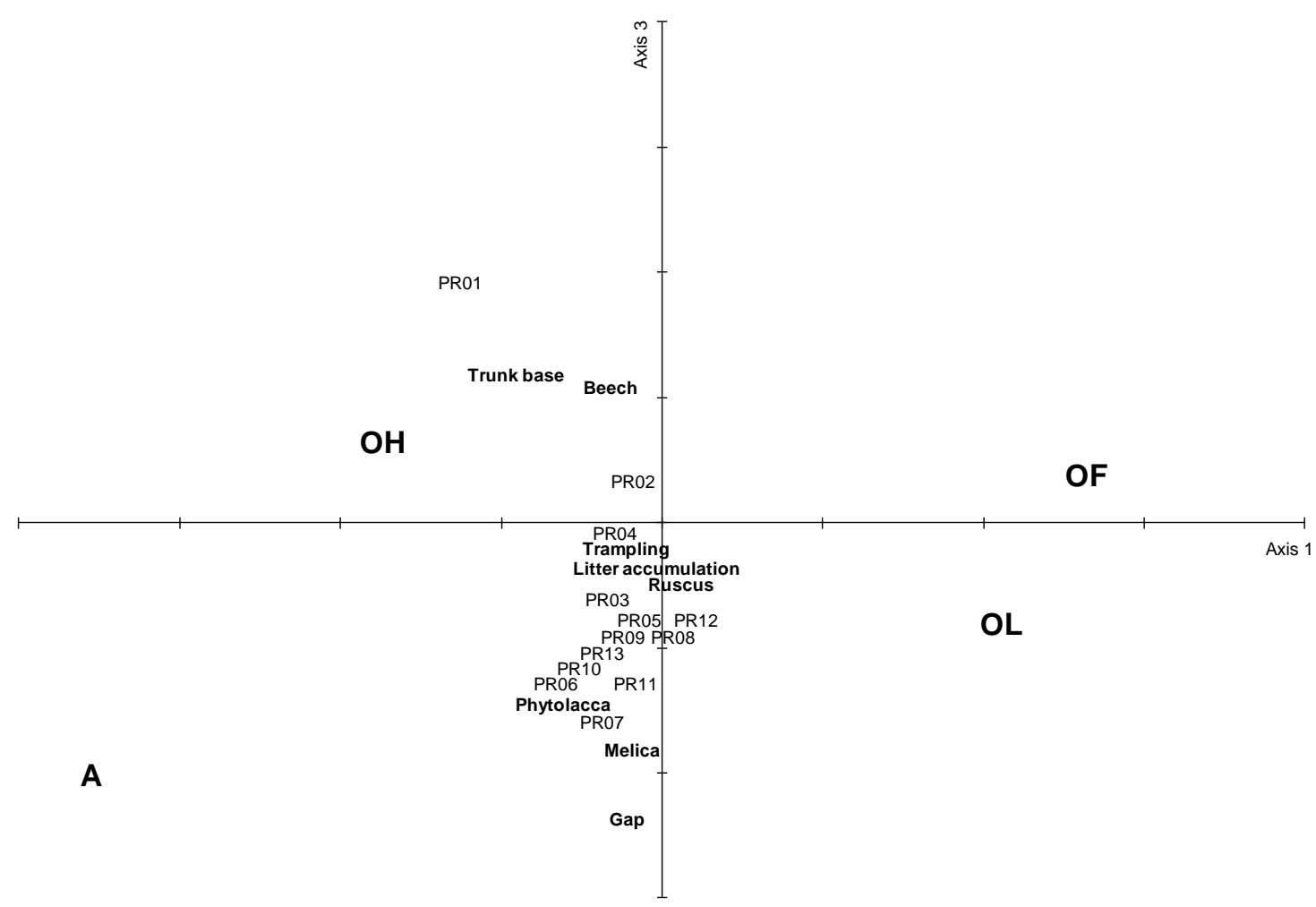

Fig. 2 


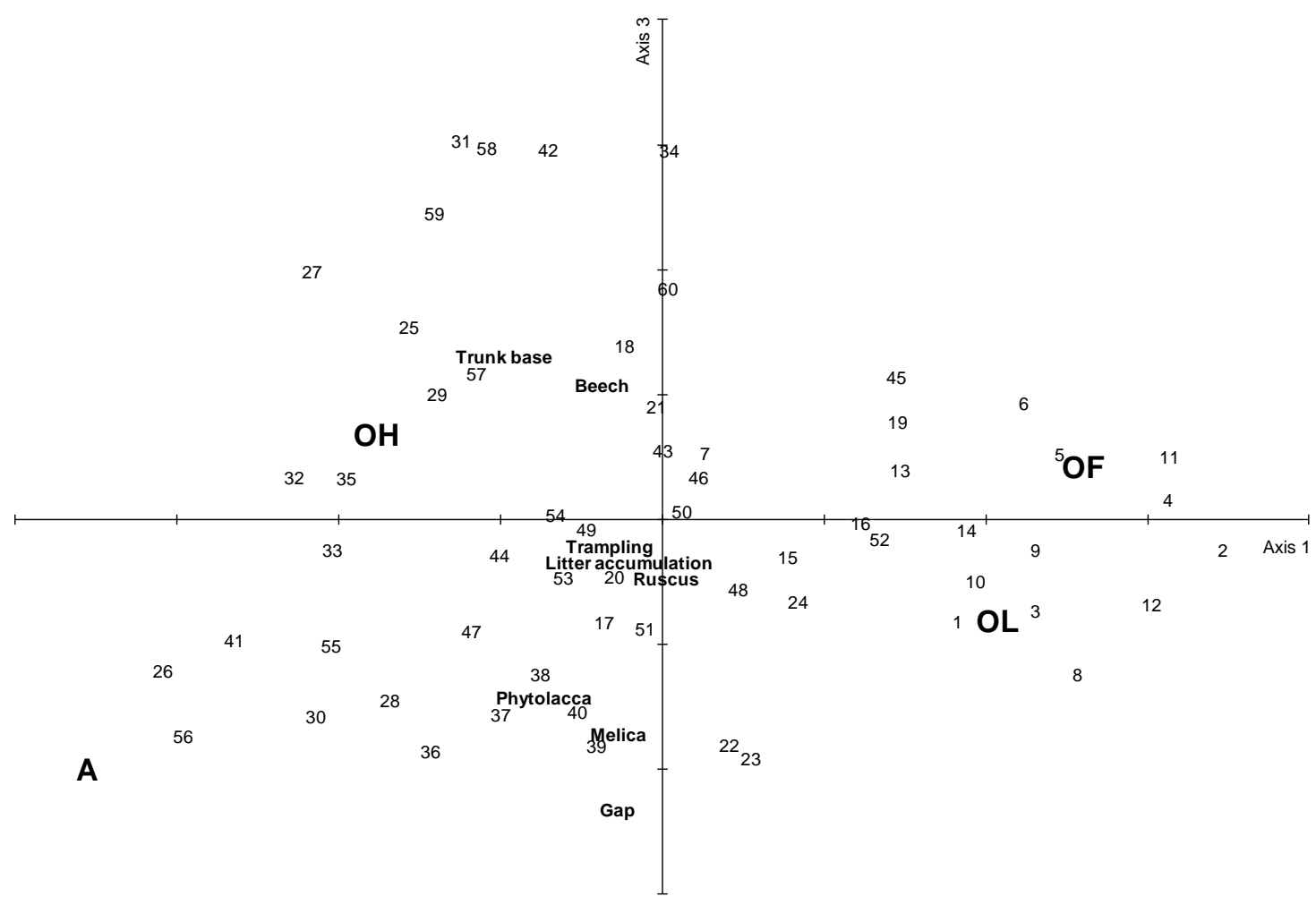

Fig. 3 